DOI 10.17150/978-5-7253-3001-4.16

B.II. III AXEPOB

УДК 336.71(571.53)

Д.Е. КОСЬМИН

ББК 65.9(2Р-4Ир)262

\title{
СПЕЦИФИКА КРЕДИТНО-ФИНАНСОВОЙ ДЕЯТЕЛЬНОСТИ БАНКА ЕЛИЗАВЕТЫ МЕДВЕДНИКОВОЙ
}

В статье поднимается вопрос об истории становления частного банка Елизаветы Медведниковой в г. Иркутске. Рассмотрена специфрика кредитно-фринансовой деятельности учреждения на протяжении всей его работы. Проведен анализ взаимодействия банка с местными органами власти. Данная статья будет интересна специалистам в области развития кредитного дела в Сибири.

Ключевые слова: частный банк, Е. Медведникова, Иркутск, финансы.

V.P. SHAKHEROV

D.E. KOSMIN

\section{THE SPECIFITY OF CREDIT AND FINANCIAL ACTIVITY OF THE ELIZAVETA MEDVEDNIKOVA'S BANK}

The article touches upon question about history of becoming Elizaveta Medvednikova's bank in the city of Irkutsk. It was considered the specificity of credit and financial activity of the bank the whole period of his work. Particular attention was paid to research the charter of bank and his evolution. The author analyzes interaction between credit organization and local authorities. It was noted bank's influence on financial activity and facilitating economic development for Irkutsk.

Keywords: Irkutsk, private bank, Elizaveta Medvednikova, finance. 
В истории становления и развития кредитного дела в России банки, как крупные фринансовые учреждения, несомненно, играют огромную роль. С расширением внутреннего и внешнего рынка, становлением новых отраслей производства, появлением крупных промышленных предприятий связана прямая потребность в кредитных учреждениях. Постепенно вытесняя мелкие формы займа, банк как кредитное учреждение особого фрормата, становится важнейшим звеном в экономическом процессе - стимулирует и способствует повышению денежного оборота, обеспечивая экономический рост определенного региона или города.

Первый частный банк в Иркутске появился 1837 г. при Сиропитательном доме Е. Медведниковой. С него начинается история кредитного дела в городе.

Иркутский купец первой гильдии Иван Логгинович Медведников был крупным золотопромышленником, вел торговлю на Кяхте. В разные годы за обширную коммерческую, общественную, благотворительную деятельность был удостоен правительственных наград. Важным делом для города является созданный им банк. Главное то, что это был не просто частный банк. Идея его создания заключала основную благотворительную цель: источник материального обеспечения Сиропитательного дома, а в условиях расширения торговли, различных отраслей хозяйства, особенно с началом сибирской золотопромышленности, кредитное учреждение способствовало и коммерческим интересам предпринимателей, приносило пользу горожанам.

Цель учреждения банка, как она определена Положением, что «кроме умножения средств к расширению самого заведения (Сиропитательного дома), открыта будет для торговли в Сибири купечества возможность пользоваться денежными пособиями в коммерческих их оборотах» $[1$, с. 747$]$.

Банк принимал в учет векселя Почетных граждан, Иркутских купцов, мещан, цеховых, иногородних купцов, имеющих торг и постоянное жительство в Иркутске.

Вести дела банка было поручено Совету, который учреждается для управления Сиропитательным домом. Совет состоит из старшего попечителя, которым пожизненно был назначен И. Л. Медведников, двух попечителей и двух кандидатов к ним, избираемых городским обществом на три года из почетных граждан и купцов г. Иркутска. Эти лица должны были самостоятельно управлять делами банка, где установлен коммерческий порядок делопроизводства, но они не могли ни учитывать в банке своих векселей, ни пользоваться ссудами под залог движимого имущества, за исключением процентных бумаг.

По действиям своим Банк имел следующие книги: Журнал, Кассу, Ресконтро, Главную книгу, книгу для записки векселей и залогов. Капи- 
тал и документы банка по Положению хранились в Иркутском Окружном Казначействе. О своей деятельности Совет представлял годовые отчеты: городскому обществу, почетным попечителям, генерал-губернатору, министру внутренних дел, Государыне Императрице. Утверждаются отчеты Совета городским обществом и никакой ревизии не подлежат. По Положению определяется только формальная проверка с книгами и документами банка, для чего городское общество может прислать от себя двух или трех лиц из купеческого сословия. Совет ежемесячно свидетельствует денежную сумму и документы по книгам банка. Во внутренний распорядок действий Совета городское общество не может в него вмешиваться.

Из чего следует вывод, что деятельность Совета банка происходит совершенно независимо от какого-либо учреждения. Можно предположить, что Положение 1837 г. не создает никакого органа для контроля его действий. Скорее всего, институту попечителей придавалось значение как руководящей инстанции, контролирующей правильность действий Совета по управлению Сиропитательного дома и банка.

На все вообще обращающиеся в банке вклады Положение установило 4 \% годовых, на вклады, которые пробыли в банке менее года, процентов вовсе не начисляются [1, с. 748]. Билетам банка Е. Медведниковой было дано весьма важное преимущество. Во всех правительственных и частных местах они принимались наравне с наличными деньгами и как билеты государственных банков, могли передаваться посредством надписей одного лица другому. Это преимущество было своего рода правительственной гарантией и имело значение для упрочения банка.

Ссуды могли выдаваться банком под учет векселей и под залоги государственными и частными процентными бумагами, товаров, драгоценных вещей и каменных зданий. Этот пункт можно назвать преимуществом банка, который не был ограничен лишь только принятием ценных бумаг. Безусловно, такие возможности банка способствовали не только выдачи крупных капиталов для торговли, но и небольшой суммы на покупку необходимых на тот момент вещей. На все ссуды определен рост из $6 \%$ в год [1, с. 750]. К учету принимались векселя иркутских купцов, мещан и цеховых, иногородних купцов, которые имеют торг и постоянное жительство в Иркутске на срок не более одного год и не менее одного месяца.

Высший предел ссуды под учет векселей, который банк мог выдать одному лицу, был определен в 2000 р. ассигнациями, высшим же пределом суммы к учету векселя определен в 10000 р. [1, с. 750]. Возможно, подобное ограничение вызывалось стремлением, чтобы небольшой основной капитал банка, рассчитанный на большее количество клиентов, подвергся бы меньшему риску. Но в большинстве торговля принадле- 
жала крупным купцам, и сумма в 2000 р. ассигнациями или 570 р. серебром была бы чрезвычайна мала. Спасало банк то, что для торговли того времени необходим был кредит, и предлагаемой суммой никто не пренебрегал.

Ссуды под залог правительственных процентных бумаг могли выдаваться в размере равном их номинальной цене. Под залог акций частных промышленных компаний, опираясь на курс, выдавали половину их номинальной стоимости. В залог принимались акции пользующихся покровительством правительства российских компаний, в том числе акции Российско-Американской компании, которых было достаточно много у иркутян. Принималось движимое имущество, драгоценные камни, товары и др. Они могли быть приняты в ссуду по оценке их присяжным городским ценовщиком под наблюдением одного из члена Совета. Под залог вещей можно было выдавать не более половины, под залог товаров только третью часть стоимости по оценке. Срок ссуд под залог процентных бумаг зависел от усмотрения Совета, ссуды под залог акций частных компаний не могли выдаваться сроком более двух лет. Под залог драгоценных вещей выдавались ссуды под залог на 4, 8 и 12 месяцев, под залог товаров на 4 и не более 6 месяцев [1, с. 751]. При залоге вещей выдавались установленные билеты, отмечалась ссуда в книгах банка.

Заложенные бумаги, вещи и товары могли быть проданы залогодателям, только в случае уплаты всей суммы долга. Для выкупа заложенных в банк предметов давалось 10 дней льготы, по истечении которых на заемщика начислялась пеня в размере одного процента в месяц на всю занятую сумму. По прошествии 3-х месяцев с того дня, когда истек срок платежа, заложенные предметы продавались с аукционного торга [1, с. 752].

Из недвижимого имущества в залог могли быть приняты только каменные здания, находящиеся в черте города Иркутска и принадлежащие всем городским сословиям, за исключением цехового, объясняется бедностью сословия и невозможностью его приобретать такую собственность. Оценка должна была производиться городовым магистратом через посредство присяжных оценщиков, уже без надзора члена Совета, в оценку только входили только несгораемые части зданий, стоимость земли в расчет не принималась. По оценке, таким образом, здания сумма могла выдаваться не более половины оценочной суммы. При взыскании не внесенных в срок ссуд такого рода, Совет должен был руководствоваться теми же правилами, которые указаны выше для взыскания ссуд под залог движимого имущества.

Раздел ссуд под залог недвижимого и движимого имущества был проработан не во всем. Положение не разграничивает их по категориям благонадежности, ценности, предлагаемые к залогу, не определяет способ их оценки, не определяет, какая часть действительной их стои- 
мости может быть дана в ссуду залогодателю, предоставляя все на благоусмотрение Совета. Но такая неопределенность могла дать широкий произвол Совету, даже если сослаться на его беспристрастность, могла создать поводы к недоразумениям и неудовольствию клиентов, влияя не самым лучшим образом на репутацию банка.

Рассматривая Положение в целом, нельзя не отметить, что оно не создает сословную исключительность, стремится к тому, чтобы все слои населения могли в равной мере воспользоваться кредитом. Таким образом, Банк Елизаветы Медведниковой был учреждением всесословным, доступным для всех и каждого из иркутских граждан, нуждающихся в кредите. Даже право учета векселей, операции, не было ограничено ни для одного из сословий г. Иркутска.

Деятелям первых лет необходимо было создать прочную репутацию заведующих учреждениями. Так поставить дело, чтобы оно дало возможность не только содержать Сиропитательный дом, но и быстро увеличить капитал банка, доказав этим, что в умелых руках даже с маленьким капиталом можно оказать значительную услугу обществу. Благодаря первым Советам банка проводилась прогрессивная политика в решении ряда вопросов в делах банка, что в дальнейшем послужит поводом для пересмотра Положения 1836 г. и разработкой полноценного устава. Колоссальная работа была проделана первыми составами Совета, заложившими прочный фундамент для стабильного развития дел банка.

7 декабря 1845 г. Высочайшим указом был утвержден первый устав Иркутского Сиропитательного дома Елизаветы Медведниковой и учрежденного при нем банка.

К первым параграфам устава о целях учреждения банка, помимо коммерческой и благотворительной, добавлялась еще третья - доставлять через прием временных вкладов в банк разным местам и лицам близкие и верные средства к сохранению своих капиталов [2, с. 181]. Рекомендовалось всем учреждениям, обязанным помещать свои капиталы в государственные кредитные установления, помещать их в банк Е. Медведниковой.

Наиболее крупным нововведением в разработанном Советом уставе было разделение вкладов на три разряда. К первому были отнесены все вклады, имеющие благотворительное назначение; ко второму - капиталы заведений и мест, капиталы городских обществ, городских дум, городовых и сиротских судов и ратуш; к третьему разряду причислены капиталы опек и частных лиц.

В разделе «О ссуде под учет векселей» дается полное пояснение ведения финансовых операций. Раздел дополняется новыми статьями. Была установлена высшая сумма выдачи ссуды не 2000 р. ассигнациями, а 2000 р. серебром [2, с. 183]. 
Относительно ссуд дозволено принимать в залог деревянные застрахованные строения и видоизменен способ их оценки: за основания оценки была принята доходность здания, а не его стоимость по материалам и работ, как было указано Положением. Было важным, что, наконец, устанавливались: убытки по операциям банка, если соблюдены все правила и всевозможная предосторожность, падают на доходы банк, а не управляющих им лиц [2, с. 183].

В 1860-е при г. банке им. Е. Медведниковой была открыта Сберегательная касса. Циркулярным предписанием Министра Внутренних Дел губернатором от 20 ноября 1862 г. было предложено учредить по городам городские Сберегательные кассы [5, с. 96]. Председательствующий в Совете Главного Управления Восточной Сибири Жуковский, учитывая, что по ст. 19 устава единственный в городе банк может принимать только круглыми суммами и не менее 100 р., что не дает беднейшим жителям средств к сохранению их сбережений, предложил Совету Сиропитательного дома рассмотреть вопрос об открытии при банке Медведниковой Сберегательной кассы [5, с. 96]. Городская Дума обратилась в Совет с предложением устройства при банке Сберегательной кассы. С одной стороны, Городской Думе было важно и удобно открытие кассы при Сиропитательном доме, потому что это избавляло ее от необходимости устраивать городскую Сберегательную кассу, для которой бы потребовался особый капитал и новые хлопоты по учреждению. С другой, для банка открытие кассы было также удобно, ведь вклады Сберегательной кассы могли бы способствовать увеличению операционных средства банка.

Проект устава был разработан самим Советом, в нем предлагалось: открывать кассу не менее двух раз в неделю, в будни вечером, а воскресенье после обеда; должны приниматься вклады от 25 к. до 25 р., высшим пределом вкладом по одной книжке установлен в 100 р. [3, с. 253]. Устав был высочайше утвержден 28 ноября 1863 г. Изменена была одна только § 2, по ней вклады Сберегательной кассы должны были состоять под ответственностью Иркутского городского общества. И 1 июня 1864 г. при Медведниковском банке открыта была сберегательная касса по понедельникам и четвергам с 9 до 11 ч. [5, с. 96].

Основной целью ее был прием небольших сумм на сохранение с приращением процентов, для доставления чрез то недостаточным всякого звания людям средств к сбережению, верным и выгодным образом, малых остатков от их расходов, в запас на будущие надобности. Сберегательная касса создавалась, в большей степени, для более бедных сословий, не имевших даже небольших капиталов.

Банк Е. Медведниковой был независимым финансовым учреждением. Взаимоотношения с городским самоуправлением в разные годы влияли на изменение отношения к данному вопросу. C 60-х гг. XIX в. 
город пытался активно навязать свой проект дальнейшего развития кредитного заведения Совету банка, все это время городское общество не имело своего банка. Выход Положения 1862 г. способствовал развитию идеи превращения банка Е. Медведниковой в городской общественный банк. С одной стороны, банк, стесненный положениями основного устава банка 1845 г., мог быть преобразован и расширен в своих фринансовых операциях, которые давали бы возможность иметь дело с еще более крупными капиталами, но с другой стороны это прямо противоречило первоначальной благородной цели учреждения банка.

Ходатайства Городского общества об отчуждении от сиропитального дома учрежденного при нем банка с обращением его в Городской Общественный банк остались без последствий. Важным фрактором того, что банк не мог отойти под управление городскому обществу, была воля самого учредителя И. Л. Медведникова, который не давал своего согласия на преобразование банка. Следующим фрактором было то, что эти заведения состояли под покровительством императорского Величества в Ведомстве Императрицы Марии. Учреждения содержались не на средства Городского общества или Думы, поэтому они не могли вмешиваться в дела внутреннего управления сиропитательным домом и банком Елизаветы Медведниковой.

\section{Список использованной литературы и источников}

1. Об учреждении в Иркутске сиропитательного заведения и частного при нем банка [Электронный ресурс] // Полное собрание законов Российской империи. Собрание второе. - СПб. : Типография II отделения Собственной Его Императорского Величества канцелярии, 1837. - С. 739-752. - Режим доступа : http://www.nlr.ru/e-res/law_r/search.php?part=380\&regim=3

2. Высочайше утвержденный устав Иркутского сиропитательного дома Елизаветы Медведниковой и учрежденного при нем банка [Электронный ресурс] // Полное собрание законов Российской империи. Собрание второе. - СПб. .: Типография II отделения Собственной Его Императорского Величества канцелярии, 1846. - С. 172-187. - Режим доступа : http://www.nlr.ru/e-res/law_r/search. php?part $=506$ \& regim $=3$

3. Высочайше утвержденный устав Сберегательной кассы при банке Иркутского сиропитательного дома Елизаветы Медведниковой [Электронный ресурс] // Полное собрание законов Российской империи. Собрание второе. - СПб. : Типография II отделения Собственной Его Императорского Величества канцелярии, 1864. - С. 253-255. - Режим доступа : http://www.nlr.ru/e-res/law_r/search. php?part=788\&regim $=3$

4. Высочайше утвержденное Положение о Городских Общественных Банках [Электронный ресурс] // Полное собрание законов Российской империи. Собрание второе. - СПб. : Типография II отделения Собственной Его Императорского Величества канцелярии, 1863. - C. 111-125. - Режим доступа : http://www.nlr. ru/e-res/law_r/search.php?part=763\&regim $=3$ 
5. Панов. А. А. Банк сиропитательного дома Е. Медведниковой в Иркутске / А. А. Панов. - М. : Изд. Сов. Ирк. Сиропитат. Дома Елизаветы Медведниковой, 1892. - Т. $1-253$ c.

6. Шахеров В. П. Становление кредитной системы в Иркутской губернии в XVIII - первой половине XIX века / В. П. Шахеров // Историко-экономические исследования. - 2014. - Т. 15, № 4. - С. 668-694.

\section{Информация об авторах}

Косьмин Данил Евгеньевич - магистрант 2 года обучения, кафедра истории России, исторический факультет, Иркутский государственный университет, 664025, г. Иркутск, ул. Чкалова, 2; e-mail: danilevgenievich@gmail.com

Шахеров Вадим Петрович - профессор, доктор исторических наук, кафедра истории России, исторический фракультет, Иркутский государственный университет, 664025, г. Иркутск, ул. Чкалова, 2; e-mail: wodalis@yandex.ru

\section{Authors}

Danil E. Kosmin - Undergraduate, the $2^{\text {nd }}$ year of Training, Department History of Russia, History Facuity, Irkutsk State University, 2 Chkalov St., 664025, Irkutsk, Russia; e-mail: danilevgenievich@gmail.com

Vadim P. Shakherov - Professor, Doctor of History, Department History of Russia, History Facuity, Irkutsk State University, 2 Chkalov St., 664025, Irkutsk, Russia; e-mail: wodalis@yandex.ru 